\title{
Antagonist Test of Endophytic Bacteria from Roots of Rice Plant in South Sulawesi Indonesia as a Biological Agent of Bacterial Leaf Blight Disease
}

\author{
Andi Herwati ${ }^{1 *}$, Baharuddin Patandjengi ${ }^{2}$, Muh. Jayadi ${ }^{3}$ and Masniawati ${ }^{4}$ \\ ${ }^{1}$ Program of Agriculture, Graduate School, Universitas Hasanuddin. Jl. Perintis \\ Kemerdekaan Km.10, Tamalanrea, Makassar 90245, South Sulawesi, Indonesia \\ ${ }^{2}$ Department of Plant Pest and Disease, Faculty of Agriculture, Universitas Hasanuddin. Jl. \\ Perintis Kemerdekaan Km.10, Tamalanrea, Makassar 90245, South Sulawesi, Indonesia \\ ${ }^{3}$ Department of Soil Science, Faculty of Agriculture, Universitas Hasanuddin, Jl. Perintis \\ Kemerdekaan Km.10, Tamalanrea, Makassar 90245, South Sulawesi, Indonesia \\ ${ }^{4}$ Department of Biology, Faculty of Mathematics and Natural Sciences, Universitas \\ Hasanuddin, Jl. Perintis Kemerdekaan Km.10, Tamalanrea, Makassar 90245, \\ South Sulawesi, Indonesia \\ *Corresponding author
}

K e y w o r d s
Antagonist,
Bacterial leaf blight,
Isolates,
Xanthomosan
oryzae pv. oryzae L.
Article Info
Accepted:
15 October 2020
Available Online:
10 November 2020

Keywords

Antagonist,

Bacterial leaf blight,

Xanthomo

oryzae pv. oryzae $\mathrm{L}$.

Article Info

Accepted:

Available Online:

10 November 2020

\section{A B S T R A C T}

Bacterial leaf blight is a disease in rice plants caused by the bacteria Xanthomonas oryzae pv oryzae L (Xoo). Biological agents controlling plant diseases that are being developed now are endophytic bacteria that can increase plant resistance to plant pathogens. This study aims to find antagonistic bacteria that are able to provide the highest resistance to the growth of pathogenic Xoo bacteria in rice plants. Antagonistic bacteria were isolated from the leaves and roots of rice plants through surface sterilization and serial dilution. Obtained 53 bacterial isolates consisting of 20 bacterial isolates from leaves and 33 bacterial isolates from roots tested hypersensitive to tobacco plants for filtering potential non-pathogenic bacteria. 29 hypersensitive negative isolates did not occur necrotic on tobacco leaves which were tested antagonist against Xoo in vitro, found 8 isolates of antagonistic bacteria derived from leaves namely AHF9LS, AHF11LS, AHF13LS, AHF3GS, AHF7GS, AHF8GS, AHF5KS, AHF12KS and 7 isolates of antagonistic bacteria from the roots namely AHE1MS, AHE9MS, AHE15MS, AHE1LS, AHE6LS, AHE11LS and AHE23KS which have the potential to inhibit Xoo growth shown by the formation of medium, strong and very strong inhibition zones. In vivo application results of 15 bacterial isolates in rice plants found bacterial isolates with very strong inhibition that is AHE1MS with the smallest average length of the lesion observed 14 days after inoculation is $0.10 \mathrm{~cm}$ and 28 days after inoculation is $1.27 \mathrm{~cm}$. For the length of lesion in percentage of diseased leaf area AHE1MS isolate was obtained by $0.22 \%$ at 14 days after inoculation and $3.18 \%$ at 28 days after inoculation shown by AHF9LS isolates. 


\section{Introduction}

One of the main diseases in rice plants is bacterial leaf blight (BLB) caused by the bacterium Xanthomonas oryzae pv oryzae $L$. (Xoo). BLB can damage rice plants from the nursery to near harvest with two typical symptoms. Crackle is a symptom of disease arising in the seedling phase, marked on the edge of leaf there are wet patches, pale green leaves and curled (Nurkartika et al., 2017). Symptoms of disease in adult plants are marked with orange-yellow on the edge of the leaf, leaf tip, or part of the leaf that has mechanical damage, looks like submerged in hot water and then extends toward the base of the leaf called a blight. This disease can result in yield losses of up to 50-70\% (BPTP, 2018). One alternative currently being developed to control bacterial leaf blight disease more wisely and increase production is application of biological agents that can enhance growth and protect plants from disease through several mechanisms (Nurkartika et al., 2017). According to Bhore et al., (2010) biological control agents of plant diseases that are currently being developed are endophytic bacteria. Endophytic bacteria are bacteria that live in the tissues of host plants without causing symptoms of the disease.Endophytic bacteria are reported in addition to increasing plant growth can also induce plant resistance to plant pathogens.

Endophytic bacteria can directly increase plant resistance by releasing certain compounds in pathogenic niches, as an antagonism, inducing plant resistance systems, and increasing plant tolerance to biotic environmental pressures (Hallman 2001). In addition endophytic bacteria can support the growth of host plants by producing plant growth regulators, helping fixation of nitrogen, producing antibiotic compounds that induce host plant resistance to pathogens and parasites, and producing antibiotics (Bhore et al., 2010; ReinholdHurek and Hurek 2011; Wiratno et al., 2019). According to Reinhold-Hurek and Hurek (2011), Leiwakabessy and Latupeirissa (2013), Wiratno et al., (2019) endophytic bacteria can protect plants against pathogens through induction mechanism of plant defense, competition in obtaining nutrition and space to conduct colonization and secretion of substances that are antagonistic to pathogens. Endophytic bacteria that colonize the internal tissues of their host plants are protected from competition with other microbes and environmental stress (Hallmann et al., 1997; Balosi et al., 2014). Endophytic bacteria that are used as biological agents and growth stimulants provide better benefits than free-living microorganisms because they do not compete in complex ecosystems (Compant et al., 2005; Yulianti, 2013).

This study aims to find antagonistic bacteria that are able to provide the highest resistance to the growth of pathogenic Xoo bacteria in rice plants.

\section{Materials and Methods}

\section{Study area}

The plant material used is the roots and leaves of healthy rice plants obtained from several regions in Soppeng district, namely Galung Village, Pattojo, Rompegading, and Timusu. Bacteria were isolated by surface sterilization method of Hallmann et al., (2001), roots and leaves of rice were cleaned and cut in 1-2 cm size then immersed in $70 \%$ alcohol for 1 minute and in $\mathrm{NaOCl} 2.5 \%$ for 2 minutes then rinsed 3 times with sterile water for 3 minutes. The cuttings of roots and leaves were each applied to Nutrient Agar (NA) medium and incubated for 48 hours. Selected isolates are bacteria that do not grow on NA medium. Furthermore, the plant material is mashed with sterile mortar and mixed with 10 
$\mathrm{ml}$ of sterile water (Fig. 1). $1 \mathrm{ml}$ of suspension of plant material is homogenized with $9 \mathrm{ml}$ of sterile water in a test tube and diluted in series with concentrations of $10^{-2}, 10^{-3}$, and $10^{-4}$. Each dilution of $0.1 \mathrm{ml}$ was spread on NA medium and incubated for 48 hours. Bacterial colonies were purified into NA media to obtain pure culture (Ramos, 2004; Risan, 2017; Kristiana et al., 2019).

\section{Hypersensitive reactions of bacterial isolates}

Hypersensitive reaction test on tobacco leaves (Nicotiana tabacum) based on the method carried out by Schaad et al., (2001) to determine bacterial isolates as plant pathogens. Each isolate was grown on liquid NA medium, incubated for 24 hours in a rotary shaker to a population density of $10^{9} \mathrm{cfu}$ / ml (Harni and Ibrahim, 2011). Each inoculum was infiltrated as much as $1 \mathrm{ml}$ using a $1 \mathrm{ml}$ sterile syringe without needle on the underside of a healthy tobacco leaf. Positive control was used Xanthomonas oryzae, while sterile distilled water as negative control. Plant response is observed in 24-48 hours. Isolates that do not cause necrosis produce a negative hypersensitive reaction (Abdallah et al., 2016).

\section{Antagonistic test of bacterial isolates against $\mathrm{Xoo}$ in vitro}

This test was carried out to determine the ability of bacterial isolates to inhibit Xoo growth and find potential isolates as biological agents. Testing is done by double layer method (Lisboa et al., 2006). The liquid culture of pathogenic bacteria as much as 800 $\mu \mathrm{L}\left(10^{7} \mathrm{cfu} / \mathrm{ml}\right)$ was inoculated into $80 \mathrm{ml}$ NA semi-solid. $10 \mathrm{ml}$ is poured on a solid NA surface. Paper disk (0.7 cm diameter) is soaked was immersed in a 24-hour-old bacterial solution, then dried and placed in a petri dish containing Xoo bacteria on NA media. The culture was incubated at $37^{\circ} \mathrm{C}$ for 24 hours and diameter of inhibition zone formed was then observed. Antibacterial activity is positive if an inhibitory zone is formed around the paper disk. Control treatment with sterile distilled water. The antimicrobial activity index is calculated based on the method by Patra et al., (2009). Inhibition abilities are grouped based on inhibitory indexes which are very strong (> 3.0) with symbols (++++), strong (2.0-2.9) with symbols $(+++)$, moderate $(1.0-1,9)$ with symbols $(++)$, weak (0.1-0.9) with symbols $(+)$ and do not have antagonistic abilities (0.0) with symbols (-). Inhibition index (IH) is calculated based on the formula:

$\mathrm{IH}=\frac{\text { Clear Zone Diameter-Blank Discs Diameter }}{\text { Blank Discs Diameter }}$

\section{Application of antagonistic bacterial isolates in vivo to rice plants}

Inpari 32 rice seedlings that will be sown are cleaned with $95 \%$ alcohol for 1 minute then washed with sterile distilled water three times for 3 minutes. Selected seeds are sunk and wrapped in gauze for 4 days to germinate, then planted in a $15 \times 30 \mathrm{~cm}^{2}$ pot filled with sterile growing media. 21-day-old rice seeds are transferred to pots with a diameter of 30 $\mathrm{cm}$ and each pot is planted with 2 clumps of rice. The selected antagonistic bacteria are bacteria with strong to very strong inhibition patterns in the in vitro test. Xoo colonies were grown on liquid NA medium with a density of $10^{9} \mathrm{cfu} / \mathrm{ml}$ (Yashitola et al., 2002). Spraying was carried out before inoculation of pathogen Xoo (preventive) of $30 \mathrm{ml}$ of bacterial suspension at 7 days, 14 days, 21 days, and 42 days after planting. At the age of 45 days, pathogen Xoo was inoculated by leaf clipping method with five rice leaves in each clump. The control treatment was sprayed with sterile aquades, as well as pain control inoculated with Xoo. Symptoms of bacterial leaf blight were observed after 14 and 28 days 
after inoculation through measurement of the lesion length of bacterial leaf blight using the formula:

Th Disease Leaf Area $(\%$ DLA $) \frac{\text { Total length of lesion of test sample }}{\text { Total length of of leaves of test sample }} \times 100 \%$

\section{Results and Discussion}

\section{Isolation of antagonistic bacteria from rice plants}

The results of isolation of biological agents from roots and leaves of rice plants are presented in Table 1. Obtained 53 isolates can grow and colonize NA media. 20 isolates originated from leaves and 33 originated from roots (Figure 2). NA medium is a medium used to observe the appearance or morphology of bacterial colonies and contains nutrients for the growth of non-selective microorganisms (Rossita et al., 2016).

\section{Hypersensitive reactions of bacterial isolates}

53 bacterial isolates that had been obtained were tested hypersensitive to tobacco leaves (Table 1). 29 hypersensitive negative isolates did not occur necrosis there was no change in tobacco leaves and 24 hypersensitive positive isolates caused tobacco leaves to become necrotic (Figure 3). According to Danaatmadja et al., (2009) hypersensitivity testing in tobacco is a screening of potential non-pathogenic bacteria even though some pathogens give negative results. Hypersensitivity is a defense mechanism that can inhibit the attack of microorganisms. Characteristically, infected cells have increased permeability, deficiency, and death from host cells.

This is consistent with the observation of Wiratno et al., (2019) that hypersensitivity reactions arise in plant tissue are necrotic due to the plant's response to pathogens and are an attempt to inhibit pathogen growth.

\section{Antagonistic bacterial isolate test in vitro}

29 bacterial isolates which did not cause necrotic symptoms on tobacco plants were tested antagonist against Xoo in vitro (Figure 4), found 8 isolates of antagonistic bacteria derived from leaves and 7 isolates of antagonistic bacteria from roots that have strong and very strong inhibitory potential to inhibit Xoo growth is indicated by the formation of inhibitory zones (Table 2).

This is consistent with observations by Octriana (2011), that the growth of pathogens is inhibited due to competition with biological agents causing the pathogen not have room for its place of life. This is because competition occurs when there are two or more microorganisms that directly require the same source of nutrition. The difference in inhibition zones is thought to be due to the condition and nutrient content of media used (Saputra et al., 2015).

In addition to the mechanism of inhibition through nutrition and space competition also has an antibiotic inhibition mechanism. Besides that, according to Vann Loon (2000) and Putro et al., (2014) biological control by antagonistic bacteria can occur through one or several mechanisms such as in biological microbial controllers, namely: antibiosis, competition, hyper-parasite. The difference in inhibition of each isolate is caused by different inhibitory mechanisms. This is in accordance with opinion of Pal and Gardener (2006) and Kurniawati et al., (2015) the production of bioactive compounds such as degrading enzymes, bioactive compounds and other compounds such as carbon dioxide, ammonia and hydrogen cyanide that can inhibit growth and kill other microorganisms which are the mechanism of antibiosis. Antibiotic compounds act as induction agents (elicitors) capable of providing plant resistance to disease. Walters et al., (2013) and Hanudin et al., (2016) states that 
resistance induction can be done through application of biological agents (such as nonpatogenous rhizobacteria) and chemical compounds (synthetic and vegetable) can be used as an induction of resistance. The success of inducing compounds ranges from $20-89 \%$ in controlling the attack of plant pathogens, depending on physiological conditions, plant species, and abiotic factors such as temperature and humidity.

\section{Antagonistic bacterial isolate test in vivo on rice plants}

In vivo application results showed that bacterial isolates were able to inhibit the growth of diverse Xoo on rice leaves. This shows that all endophytic bacterial isolates tested have the potential to be antagonistic to Xoo. Bacterial isolates with very strong inhibition were AHE1MS with the smallest average length of the lesion that is $0.10 \mathrm{~cm}$ at 14 days after inoculation and $1.27 \mathrm{~cm}$ at 21 days after inoculation. These results indicate that ability of antagonistic bacterial isolates in suppressing the growth of Xoo pathogenic bacteria. This is consistent with observations made by Zheng et al., (2012), inhibition of pathogen growth by antagonistic bacteria is indicated by a delay in development of symptoms. The use of antagonistic microbes can produce antibiotic compounds that can inhibit the growth of pathogens so that their growth is faster than pathogen. Shehata et al., (2008) states that antagonistic bacteria produce different amounts of antibiotics so that they have different inhibiting abilities. Antagonistic bacteria as bio-control agents must have the ability to survive in order to suppress the transmitted infection. Because only antagonistic bacteria can survive on plant parts that are efficient and effective in managing transmitted infections.
The lowest percentage observation of leaf area was found in AHE1MS isolates of $0.22 \%$ at 14 days after inoculation and $3.18 \%$ at 21 days after inoculation shown by AHF9LS isolates. Obtained isolates that have a strong inhibitory to the growth of Xoo at e in vitro level differed at in vivo level. This is consistent with the results of Mew et al., (2004) and Rustam et al., (2011), when antagonistic bacteria are applied at different places and times, the ability to inhibit antagonistic bacterial isolates in vitro is often inconsistent with in vivo applications in the field. This indicates the influence of environmental conditions on the growth and development of bacterial isolates that are applied so that it is less adaptive at in vivo level which causes the antagonistic potential it has to play less role as at in vitro level (Rusatam et al., 2011).

Based on observations obtained isolates that have a strong inhibition against Xoo. QuadthHallmann et al., (1997) and Zuraidah (2013) stated that isolates which have strong inhibition on Xoo growth. One important aspect for efficacy of biocontrol agents is internal colonization of rice leaves by bacteria that can determine antagonistic activity in protecting stomata area of rice leaves and ability of bacterial cells to enter plant tissue while competing with other bacteria associated with plants.

Based on observations of the application of biological bacteria that are antagonistic, it is more effective in suppressing Xoo growth when the rice plants are in generative growing stage, namely age $7,14,21$, and 42 days after planting. This is consistent with observations by Utkhede (2005) and Zuraidah (2013) biocontrol agents are generally more effective when applied before disease develops as a preventive treatment (Table 3). 
Table.1 Results of isolation and hypersensitive reactions of antagonistic bacteria from rice plants

\begin{tabular}{|c|c|c|}
\hline Bacterial isolate & Antagonistic bacterial origin & Hypersensitive reaction \\
\hline AHF3MS & Leaf & + \\
\hline AHF4MS & Leaf & + \\
\hline AHF7MS & Leaf & - \\
\hline AHF9MS & Leaf & + \\
\hline AHF15MS & Leaf & + \\
\hline AHF8LS & Leaf & + \\
\hline AHF9LS & Leaf & - \\
\hline AHF11LS & Leaf & - \\
\hline AHF13LS & Leaf & - \\
\hline AHF16LS & Leaf & - \\
\hline AHF3GS & Leaf & - \\
\hline AHF5GS & Leaf & - \\
\hline AHF7GS & Leaf & - \\
\hline AHF8GS & Leaf & - \\
\hline AHF3KS & Leaf & - \\
\hline AHF4KS & Leaf & + \\
\hline AHF5KS & Leaf & - \\
\hline AHF8KS & Leaf & - \\
\hline AHF12KS & Leaf & - \\
\hline AHF13KS & Leaf & + \\
\hline AHE1MS & Root & - \\
\hline AHE2MS & Root & + \\
\hline AHE6MS & Root & + \\
\hline AHE8MS & Root & - \\
\hline AHE9MS & Root & - \\
\hline AHE13MS & Root & + \\
\hline AHE14MS & Root & + \\
\hline AHE15MS & Root & - \\
\hline AHE1LS & Root & - \\
\hline AHE4LS & Root & + \\
\hline AHE5LS & Root & + \\
\hline AHE6LS & Root & + \\
\hline AHE9LS & Root & - \\
\hline AHE11LS & Root & - \\
\hline AHE12LS & Root & - \\
\hline AHE13LS & Root & + \\
\hline AHE15LS & Root & - \\
\hline AHE20LS & Root & - \\
\hline AHE2GS & Root & - \\
\hline AHE4GS & Root & - \\
\hline AHE5GS & Root & + \\
\hline AHE6GS & Root & - \\
\hline AHE8GS & Root & + \\
\hline AHE10GS & Root & + \\
\hline AHE5KS & Root & + \\
\hline AHE14KS & Root & - \\
\hline AHE15KS & Root & + \\
\hline AHE16KS & Root & + \\
\hline AHE17KS & Root & + \\
\hline AHE20KS & Root & + \\
\hline AHE21KS & Root & + \\
\hline AHE22KS & Root & - \\
\hline AHE23KS & Root & - \\
\hline
\end{tabular}

Note: +: positive reaction, -: negative reaction 
Table.2 Inhibition of Xoo by antagonistic bacterial isolates in the double layer test

\begin{tabular}{|c|c|c|c|c|c|}
\hline \multirow[t]{2}{*}{ Bacterial isolate } & \multicolumn{3}{|c|}{ Colony diameter } & \multirow[t]{2}{*}{ Inhibition index } & \multirow[t]{2}{*}{ Ability to inhibit } \\
\hline & 1 & 2 & 3 & & \\
\hline AHF3MS & 1.4 & 1.0 & 1.2 & 0.7 & + \\
\hline AHF4MS & 0.8 & 0.7 & 0.6 & 0.0 & - \\
\hline AHF7MS & 1.2 & 1.0 & 1.3 & 0.7 & + \\
\hline AHF9MS & 0.7 & 0.7 & 0.8 & 0.0 & - \\
\hline AHF15MS & 1.3 & 1.3 & 1.1 & 0.8 & + \\
\hline AHF8LS & 1.4 & 1.3 & 1.3 & 0.9 & + \\
\hline AHF9LS & 2.5 & 2.7 & 2.7 & 2.8 & +++ \\
\hline AHF11LS & 1.8 & 1.5 & 1.6 & 1.3 & ++ \\
\hline AHF13LS & 2.0 & 2.0 & 2.1 & 1.9 & ++ \\
\hline AHF16LS & 1.3 & 1.1 & 1.2 & 0.7 & + \\
\hline AHF3GS & 1.8 & 1.6 & 1.6 & 1.4 & ++ \\
\hline AHF5GS & 0.8 & 0.6 & 0.8 & 0.0 & - \\
\hline AHF7GS & 1.6 & 1.5 & 1.9 & 1.4 & ++ \\
\hline AHF8GS & 1.4 & 1.3 & 1.3 & 0.9 & + \\
\hline AHF3KS & 2.7 & 2.8 & 2.8 & 3.0 & ++++ \\
\hline AHF4KS & 1.3 & 1.3 & 1.2 & 0.8 & + \\
\hline AHF5KS & 1.7 & 1.6 & 1.5 & 1.3 & ++ \\
\hline AHF8KS & 1.3 & 1.4 & 1.3 & 0.9 & + \\
\hline AHF12KS & 1.8 & 1.5 & 1.7 & 1.4 & ++ \\
\hline AHF13KS & 1.3 & 1.0 & 1.3 & 0.7 & + \\
\hline AHE1MS & 2.5 & 2.2 & 2.3 & 2.3 & +++ \\
\hline AHE2MS & 1.3 & 1.2 & 1.4 & 0.9 & + \\
\hline AHE6MS & 0.6 & 0.8 & 0.7 & 0.0 & - \\
\hline AHE8MS & 1.1 & 1.1 & 1.0 & 0.5 & + \\
\hline AHE9MS & 1.7 & 1.4 & 1.5 & 1.2 & ++ \\
\hline AHE13MS & 1.3 & 1.3 & 1.1 & 0.8 & + \\
\hline AHE14MS & 1.3 & 1.3 & 1.3 & 0.9 & + \\
\hline AHE15MS & 1.6 & 1.6 & 1.9 & 1.4 & ++ \\
\hline AHE1LS & 2.0 & 2.0 & 2.0 & 1.9 & ++ \\
\hline AHE4LS & 0.8 & 0.7 & 0.7 & 0.0 & - \\
\hline AHE5LS & 1.3 & 1.4 & 1.2 & 0.9 & + \\
\hline AHE6LS & 1.1 & 1.3 & 1.4 & 0.8 & + \\
\hline AHE9LS & 1.2 & 1.4 & 1.6 & 1.0 & ++ \\
\hline AHE11LS & 1.6 & 1.4 & 1.8 & 1.3 & ++ \\
\hline AHE12LS & 1.4 & 1.2 & 1.3 & 0.9 & + \\
\hline AHE13LS & 1.2 & 1.3 & 1.2 & 0.8 & + \\
\hline AHE15LS & 0.7 & 0.7 & 0.7 & 0.0 & - \\
\hline AHE20LS & 1.2 & 1.1 & 1.3 & 0.7 & + \\
\hline AHE2GS & 1.2 & 1.0 & 1.4 & 0.7 & + \\
\hline AHE4GS & 1.2 & 1.3 & 1.2 & 0.8 & + \\
\hline AHE5GS & 1.2 & 1.3 & 1.4 & 0.9 & + \\
\hline AHE6GS & 1.2 & 0.9 & 0.8 & 0.4 & + \\
\hline AHE8GS & 0.8 & 0.7 & 0.7 & 0.0 & - \\
\hline AHE10GS & 0.6 & 0.6 & 0.8 & 0.0 & - \\
\hline AHE5KS & 1.2 & 1.4 & 1.3 & 0.9 & + \\
\hline AHE14KS & 0.8 & 1.1 & 0.9 & 0.3 & + \\
\hline AHE15KS & 1.3 & 1.3 & 1.3 & 0.9 & + \\
\hline AHE16KS & 1.3 & 1.1 & 1.2 & 0.7 & + \\
\hline AHE17KS & 0.9 & 0.7 & 0.5 & 0.0 & - \\
\hline AHE20KS & 1.4 & 1.3 & 1.1 & 0.8 & + \\
\hline AHE21KS & 1.3 & 1.3 & 1,2 & 0.8 & + \\
\hline AHE22KS & 0.7 & 0.8 & 0.7 & 0.0 & - \\
\hline AHE23KS & 2.7 & 2.3 & 2.5 & 2.6 & +++ \\
\hline
\end{tabular}

Note: +: Inhibition is weak, ++: Medium inhibitory, +++: Strong inhibition, ++++: Inhibition is very strong 
Table.3 Average length of lesions and diseased leaf area in rice plants

\begin{tabular}{|c|c|c|c|c|}
\hline \multirow{2}{*}{$\begin{array}{c}\text { Antagonistic } \\
\text { bacteria }\end{array}$} & \multicolumn{2}{|c|}{ Average length of the lesion $\mathbf{( c m )}$} & \multicolumn{2}{|c|}{ Diseased leaf area $\mathbf{( \% )}$} \\
\cline { 2 - 5 } Sterile water & $\mathbf{1 4} \mathbf{~ d a i}$ & $\mathbf{2 1} \mathbf{~ d a i}$ & $\mathbf{1 4}$ dai & $\mathbf{2 1}$ dai \\
\hline AHF9LS & $0.27 \mathrm{~d}$ & $3.67 \mathrm{c}$ & 0.62 & 7.19 \\
\hline AHF11LS & $0.20 \mathrm{ab}$ & $1.60 \mathrm{ab}$ & 0.31 & 3.18 \\
\hline AHF13LS & $0.17 \mathrm{abc}$ & $1.83 \mathrm{ab}$ & 0.38 & 3.82 \\
\hline AHF3GS & $0.17 \mathrm{abc}$ & $1.80 \mathrm{ab}$ & 0.34 & 3.54 \\
\hline AHF7GS & $0,13 \mathrm{ab}$ & $1.90 \mathrm{ab}$ & 0.37 & 3.83 \\
\hline AHF8GS & $0.17 \mathrm{abc}$ & $1.83 \mathrm{ab}$ & 0.34 & 3.74 \\
\hline AHF5KS & $0.23 \mathrm{~cd}$ & $1.70 \mathrm{ab}$ & 0.34 & 3.55 \\
\hline AHF12KS & $0.20 \mathrm{bcd}$ & $2.03 \mathrm{~b}$ & 0.46 & 3.44 \\
\hline AHE1MS & $0.10 \mathrm{a}$ & $1.27 \mathrm{a}$ & 0.22 & 4.10 \\
\hline AHE9MS & $0.17 \mathrm{abc}$ & $1.97 \mathrm{~b}$ & 0.43 & 3.65 \\
\hline AHE15MS & $0.20 \mathrm{bcd}$ & $2.03 \mathrm{~b}$ & 0.45 & 3.96 \\
\hline AHE1LS & $0.17 \mathrm{abc}$ & $1.90 \mathrm{ab}$ & 0.36 & 4.04 \\
\hline AHE6LS & $0.23 \mathrm{~cd}$ & $2.00 \mathrm{ab}$ & 0.56 & 3.69 \\
\hline AHE11LS & $0.20 \mathrm{bcd}$ & $2.17 \mathrm{bc}$ & 0.48 & 4.03 \\
\hline AHE23KS & $0.13 \mathrm{ab}$ & $1.70 \mathrm{ab}$ & 0.32 & 4.36 \\
\hline
\end{tabular}

Note: Numbers followed by the same letter in the same column are not significantly different in Duncan range test at the level of 5\% Duncan Multiple Range Test (DMRT)

Figure.1 Location of sampling sites in Soppeng District, South Sulawesi, Indonesia

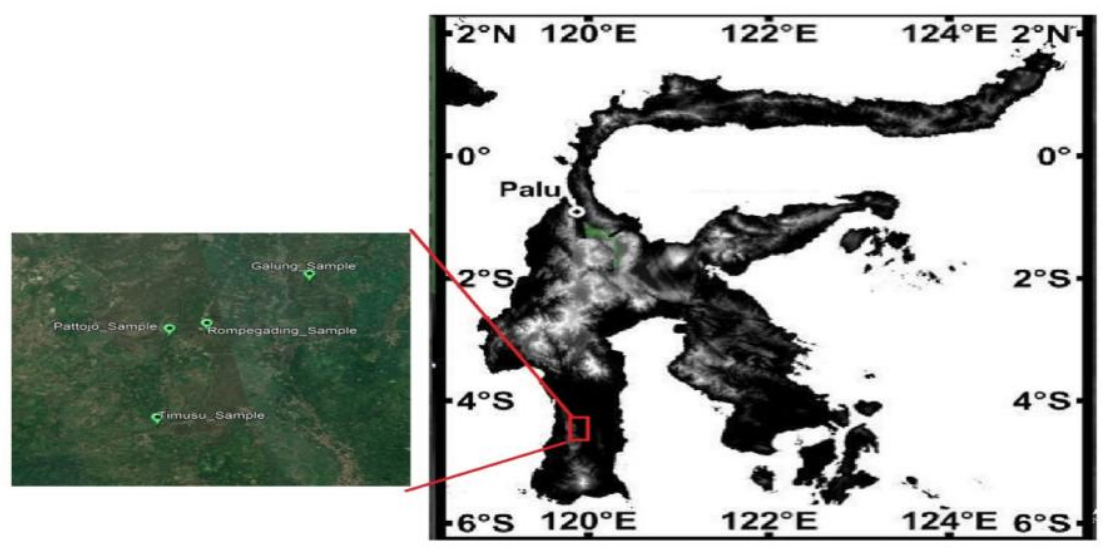

Figure.2 Isolation of endophytic bacteria from leaves and roots of rice plants. A. AHF3GS, B. AHE1MS

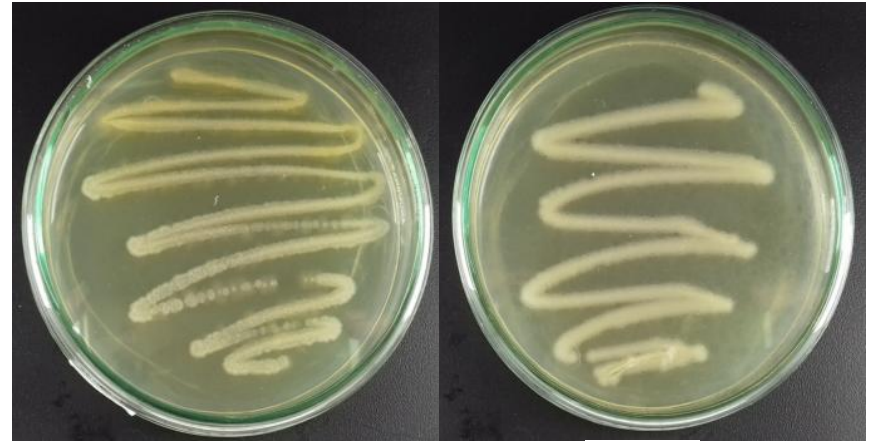

$\Delta$

$\mathbf{R}$ 
Figure.3 Hypersensitive reaction in tobacco plants 72 hours after inoculation of endophytic bacteria. A. Bacterial isolates were hypersensitive negative; B. Bacterial isolates were hypersensitive positive

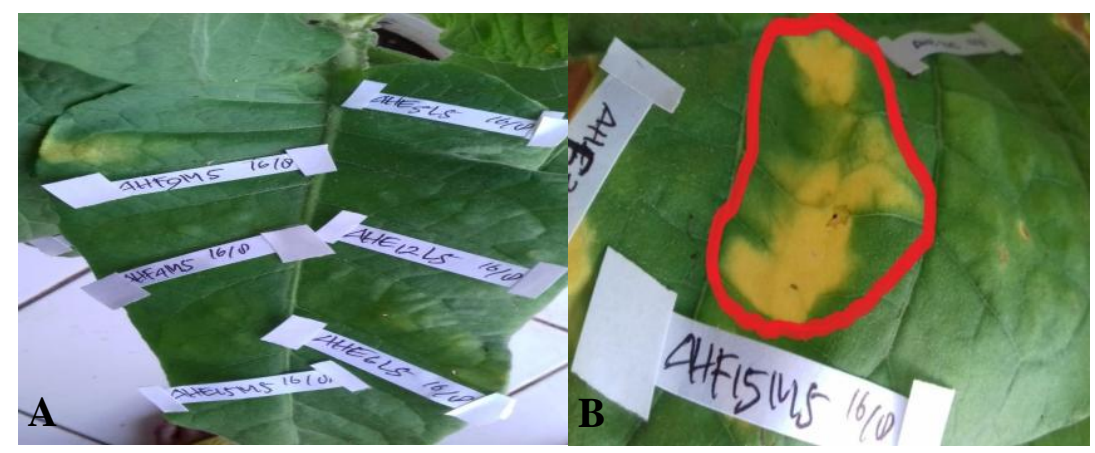

Figure.4 Antagonist test of bacterial isolates in vitro on the third day 3; A. Inhibition zone is formed, B. Without inhibition zone

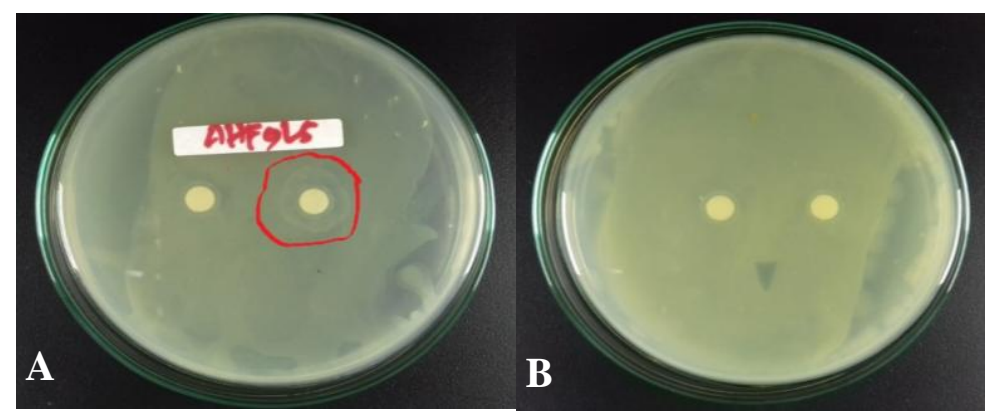

This study presents the isolation of endophytic bacteria derived from leaves and roots of rice tested for pathogenicity in healthy tobacco plants to obtain nonpathogenic bacteria and to inhibit the growth of pathogenic bacteria in rice plants. All endophytic bacterial isolates tested had the potential to be antagonistic to Xoo pathogen shown by the formation of a strong inhibitory zone. Endophytic bacteria can suppress infections that are transmitted and can survive on the plant, colonization of rice leaves can protect the stomata of rice leaves so that the potential as antagonistic bacteria as a biocontrol agent.

\section{Acknowledgements}

The author would like to show gratitude to the Kemenristekdikti-LPDP (Lembaga Pengelola
Dana Pendidikan) for funding this research, to the Promoter and Co-Promoter and all staff of Integrated Laboratory, Faculty of Agriculture, Universitas Hasanuddin for guidance and direction, and all parties involved until the process of publishing this article.

\section{References}

Abdallah RAB, Mejdoub-Trabelsi B, Nefsi A, Jabnoun-Khiareddine H, Daami-Remadi M. 2016. Isolation of Endophytic bacteria from Withania somnifera and assessment of their ability to suppress fusarium disease in tomato and to promote plant growth. Journal of Plant Pathology and Microbiology 7(5).

Balosi F, Lakani I and Panggeso J. 2014. Exploration of Endophytic Bacteria as Biological Control Agents for Blood 
Diseases in Banana Plants In Vitro. E-J Agrotekbis 2(6): 579-586.

Bhore SJ, Nithya R, Loh CY. 2010. Screening of Endophytic Bacteria Isolated From Leaves of Sambung Nyawa Gynura procumbens (Lour.) Merr. For Cytokinin-Like Compounds. Bioinformation 5(5): 191-197.

BPTP. 2018. Strategies for Controlling Bacterial Leaf Blight. Agricultural Research and Development Agency of the Ministry of Agriculture. West Kalimantan.

Compant S, Duffy B, Nowak J, Christophe C, Barka EA. 2005. Use of plant growthpromoting bacteria for biocontrol of plant diseases: principles, mechanisms of action, and future prospects. Applied and Environmental Microbiology 71(9): 1-68. DOI: 10.1128/AEM.71.9.4951

Danaatmadja Y, Subandiyah S, Joko T and Sari CU. 2009. Isolation and Characterization of Ralstonia syzygii. Indonesian Plant Protection Journal 15(1): 7-12.

Hallmann J, Quadt-Hallmann A, Mahaffee WF, Kloepper JW. 1997. Bacterial endophytes in agricultural crops. NRC Canada Can. J. Microbiol 43: 895-914.

Hallmann J. 2001. Plant Interaction with Endophytic Bacteria. In: Jeger MJ, Spencer NJ. editor. Biotic Interaction in Plant-Pathogen Associations. CAB International.

Hanudin, Nuryani W and Marwoto B. 2016. Induction of Chrysanthemum Resistance to Puccinia horiana $\mathrm{P}$. Henn. by Using Elicitor Plant Extracts. Horticultural Journal 26(2): 245-256.

Harni R and Ibrahim MSD. 2011. Potential Endophytic Bacteria Induce the Resistance of Pepper Plants to Meloidogyne incognita Infection. Littri Journal 17(3): 118-123.

Kristiana R, Sibero MT, Farisa MY, Ayuningrum D, Dirgantara D, Hanafi
M...Trianto A. 2019. Antibacterial Potential of Nudibranch-Associated Bacteria From Saparua and Nusa Laut Island, Indonesis. Biodiversitas 20(7): 1811-1819.

Kurniawati S, Mutaqin KH, and Giyanto. 2015. Exploration and Test of BioAgents Bacteria Bioactive Compounds for Disease of Rice Crackle. Journal of Tropical Plant Pests and Diseases 15(2): 170-179.

Leiwakabessy C and Latupeirissa Y. 2013. Exploration of Endophytic Bacteria as Biological Agents on Cherry Plants (Muntingia calabura L.). Journal of Agricultural Cultivation 9(1): 16-21.

Lisboa MP, Bonatto D, Bizani D, Henriques JAP, Brandelli A. 2006. Characterization of bakteriosin-like substance produced by Bacillus amyloliquefaciens isolated from the Brazilian atlantic forest. Int Microbial 9(2):111-118.

Mew TW, Cottyn B, Pamplona R, Barrios H, Xiangmin L, Zhiyi C, Fan L, Nilpanit $\mathrm{N}$, Arunyanart P, Kim PV, Du PV. 2004. Applying rice seed-associated antagonistic bacteria to manage rice sheath blight in developing countries. Plant Disease 88(5): 557-564. DOI: 10.1094/PDIS.2004.88.5.557.

Nurkartika R, Ilyas S, Machmud M. 2017. Application of Biological Agents to Control Bacterial Leaf Blight in Rice Seed Production. Indonesian Agronomy Journal 45(3): 235-242.

Octriana L. 2011. Potential of Biological Agents in Inhibiting the Growth of Phytium sp. by in vitro. Buletin Plasma Nutfah $17(2)$ : $138 . \quad$ DOI: 10.21082/blpn.v17n2.2011.p138-142.

Pal KK, Gardener BM. 2006. Biological Control of Plant Pathogens. The Plant Health Instructor. DOI:10.1094/PHI-A2006-1117-02.

Patra JK, Patra AP, Mahapatra NK, Thatoi 
HN, Das S, Sahu RK, Swain GC. 2009. Antimicrobial activity of organic solvent extracts of three marine macroalgae from Chilika Lake, Orissa, India. Malaysian Journal of Microbiology 5(2): 128-131.

Putro NS, Aini LQ and Abadi AL. 2014. Testing of Antagonistic Microbial Consortium for Controlling Anthravenous Disease in Red Chili (Capsicum annum L.). HPT Journal 2 (4): 44-53.

Quadth-Hallmann A, Hallmann J, Kloepper JW. 1997. Bacterial endophytes in cotton: Location and interaction with other plant-associated bacteria. Canadian Journal of Microbiology. 43(3): 254-259. DOI: $10.1139 / \mathrm{m} 97-$ 035 .

Ramos JL. 2004. Pseudomonas. Springer Science + Business Media New York.

Reinhold-Hurek B, Hurek T. 2011. Living Inside Plants: Bacterial Endophytes. Current Opinio in Plant Biology 14(4): 435-443.

Risan MH. 2017. Isolation and Identification of Bacteria From Under Fingernails. International Journal of Current Microbiology and Applied Sciences 6(8): 3584-3590.

Rossita AS, Munandar K, Komarayanti S. 2016. Comparison of medium NA Manufacturer with NA Modifications to the growth medium of the bacteria. National Seminar 1: 192-201.

Rustam, Giyanto, Wiyono S. Santosa DA and Susanto S. 2011. Selection and Identification of Antagonistic Bacteria as Biological Agents Controlling Leaf Blight of Rice Plant. Journal of Agricultural Food Research 30(3): 164171.

Saputra R, Arwiyanto $\mathrm{T}$ and Wibowo A. 2015. Antagonistic Activity Test of Several Isolates of Bacillus spp. Against Bacterial Wilt (Ralstonia solanacearum) in Several Tomato Varieties and Their Identification. Proceedings of National Seminar on Indonesian Biodiversity Society 1(5): 1116-1122.

Schaad NW, Jones JB and Chun W. 2001. Laboratory Guide for Identification of Plant Pathogenic Bacteria. Third Edition. Plant Pathology 50.

Shehata, Fawzy S, El-Borollosy AM. 2008. Induction of Resistance Against Zucchini Yellow Mosaic Potyvirus and Growth Enhancement of Squash Plants Using Some Plant Growth-promoting Rhizobacteria. Australian Journal of Basic and Applied Sciences 2(2): 174182.

Utkhede R. 2005. Molecular approaches for diagnosis and biological control of diseases of green house crops. In: Gnanamanickam, SS., Balasumbramaniam, R. and Anand, N. (Eds.). Procedings of the Asian Conference on Emerging Trends in Plant-Microbes Interactions. Chennai: Univ. Madras Chennai. pp.11-18. Chennai. [India].

Vann Loon L. 2000. Systemic induced resistance. Kluwer Academic Publishers, Netherlands. DOI: 10.17221/10334-pps.

Walters DR, Ratsep J and Havis ND. 2013. Controlling Crop Disease Using Induced Resistance: Challenges for the Future. Journal of Experimental Botany 64(5): 1263-1280.

Wiratno, Syakir M, Sucipto I, Pradana AP. 2019. Isolation and Characterization of Endophytic Bacteria From Roots of Piper nigrum and Their Activities Against Fusarium oxysporum and Meloidogyne incognita. Biodiversitas 20(3): 682-687.

Yashitola J, Thirumurugan T, Sundaram RM, Naseerullah MK, Ramesha MS, Sarma NP and Sonti RV. 2002. Assessment of 
Purity of Rice Hybrids Using Microsatellite and STS Markers. Crop Science 42(4): 1369-1373.

Yulianti T. 2013. The Use of Endophytes as Biological Agents Controlling Plant Pests and Diseases. Tobacco Crops, Fiber \& Industrial Oil Bulletin 5(1): 4049.

Zheng F, Liu H, Sun X, Qu L, Dong S, Liu J. 2012. Selection, identification and application of antagonistic bacteria associated with skin ulceration and peristome tumescence of cultured sea cucumber Apostichopus japonicus (Selenka). Aquaculture: 334-337. DOI: 10.1016/j.aquaculture.2011.11.009.

Zuraidah. 2013. Testing of Some Bacteria Inhibiting the Growth of Xanthomonas oryzae pv. oryzae in Rice Plants. Scientific Journal of Biological Education, Educational Biology 5(1): $18-24$.

\section{How to cite this article:}

Andi Herwati, Baharuddin Patandjengi, Muh. Jayadi and Masniawati. 2020. Antagonist Test of Endophytic Bacteria from Roots of Rice Plant in South Sulawesi Indonesia as a Biological Agent of Bacterial Leaf Blight Disease. Int.J.Curr.Microbiol.App.Sci. 9(11): 1834-1845. doi: https://doi.org/10.20546/ijcmas.2020.911.217 